\title{
Impact of Glyphosate on Agricultural Soil Quality in Sinana Woreda, South Eastern Ethiopia
}

\author{
Tesfaye Nigussie $^{1} \quad$ Dr. M. Saraswathi ${ }^{2} \quad$ Aliyi Mama $^{3}$ \\ 1.Department of Environmental Science, College of Natural and Computational Science, Madda Walabu \\ University Robe Bale, Ethiopia \\ 2.Department of Chemistry, College of Natural and Computational Science, Madda Walabu University Robe \\ Bale, Ethiopia \\ 3.Department of Environmental Science, College of Natural and Computational Science, Madda Walabu \\ University Robe Bale, Ethiopia
}

\begin{abstract}
The agronomic and socioeconomic utilities of glyphosate as a weed killer are well established in developed countries as well as in developing countries; however, our knowledge of the potential effects of glyphosate remains limited. This study was investigated the impact of glyphosate application on soil quality of agricultural land. The total of thirty two soil sample were collected from four farm lands of sinana woreda's south eastern Ethiopia and a randomized complete block design of glyphosate was applied at different rates $(0,1,2.5,3) \mathrm{Lha}^{-1}$ on the plots of design length $2 \mathrm{~m} \times$ width $2 \mathrm{~m}\left(4 \mathrm{~m}^{2}\right)$. Laboratory analyses were done for collected soil samples from land utilized for treatment in order to determine: soil moist content, texture, bulk density, $\mathrm{pH}$, total nitrogen, available phosphorous. The survey results misunderstanding, continues and long term application of glyphosate negative impacts on soil quality. The laboratory result data have been tabulated and summarized by using SPSS. For all selected physiochemical property between treatment $(0,1,2.5,3)$ Lha $^{-1}$ application of glyphosate on farm land show significant difference on more treatments but in some of the treatments no significant difference observed. Organic matter, total of nitrogen, phosphorous increased on over dosage application while moisture content and bulk density decreasing, soil acidity becomes slightly acidic. There is a need to study further on continuous application of glyphosate on farm land. In general continues application of glyphosate has impact on agricultural soil but short term application of glyphosate has no more negative impact on agricultural soil quality.
\end{abstract}

Keywords: Different doses; Farmlands; Macro nutrients and Over dose application

DOI: $10.7176 / \mathrm{CMR} / 11-10-02$

Publication date: December $31^{\text {st }} 2019$

\subsection{INTRODUCTION:}

Glyphosate (N-(phosphono methyl) glycine; $\mathrm{C}_{3} \mathrm{H}_{8} \mathrm{NO}_{5} \mathrm{P}$ ), a highly efficient broad-spectrum and non-selective herbicide, has been widely used in agriculture, horticulture, parks, and domestic gardens (Wojtaszek et al., 2004). It was first marketed in 1974 under the name Roundup by Monsanto, USA. Its use has increased rapidly with the commercial introduction of genetically modified corn, soybeans, and cotton; glyphosate-based herbicides have become the most widely applied herbicide worldwide, especially on genetically modified crops (Brookes \& Bar foot, 2015). With the intensive use of these kinds of herbicides, the occurrence of glyphosate in soil, sediment and water bodies, as Well as risks to human health (Majewski et al., 2014; Ruiz- Toledo et al., 2014; Samsel\&Seneff, 2015). With the expiration of Monsanto's patent, many other companies began producing relatively inexpensive generic equivalents (Livingston et al., 2015).

After application, herbicides may evaporate (volatilize) and washed away through surface run-off or leached into deep soil strata and ground water, they may be inactivated by plants or adsorbed in soil and become subjected to chemical degradation (Kortekamp, 2011). They are considered specific regarding their toxic level their application may lead to synergy and development of toxicity-hazardous to soil biota (Michaelidou et al., 2000).

Effects of glyphosate residues in soil when it is applied as a spray in ecological restoration, a situation where the common spray application technology has a risk of high herbicide delivery rate, regardless of whether the concentration used conforms to the label recommendation or not. High delivery volumes will result in run-off from leaves to soil operator error delivering excessive dose rates appears to present the real problem (Cornish \& Burgin, 2005).

Glyphosate use in agricultural land has effect on Environmental and ecological to loosen the soil and for favorable seed bed, severe erosion and other additional land degradation, in addition the rate of glyphosate application might be not enough for the weed control on the farmer's field of those farmers also might have less awareness, less technical skill and not convinced about the effectiveness of the herbicide in northern Ethiopia (Teamti\&Tesfay, 2016).

In view of present agricultural methods, intensification of farming should not lead the accumulation of some organic molecules like glyphosate in the soils. Even though the soil quality issue is serious, there is no such research conducted on impact of glyphosate application including the over dose and under dose effect on soil 
quality on the present study area, which resides in south eastern Ethiopia. So the present study aimed that the experimental evolution of soil quality of agricultural lands in four selected farm lands of sinana woreda by applying glyphosate at different dosage.

\subsection{METHODOLOGY}

The proposed study was conducted in Sinana woreda, Bale Zone, Southeastern part of Ethiopia. It is located 430 $\mathrm{Km}$ far from the capital city of the country, Addis Ababa. Sinana Woreda is situated between $6.91^{0}$ to $7.28^{0}$ latitude and $39.9^{0}$ to $40.37^{\circ} \mathrm{E}$ longitude (SWAO, 2017).

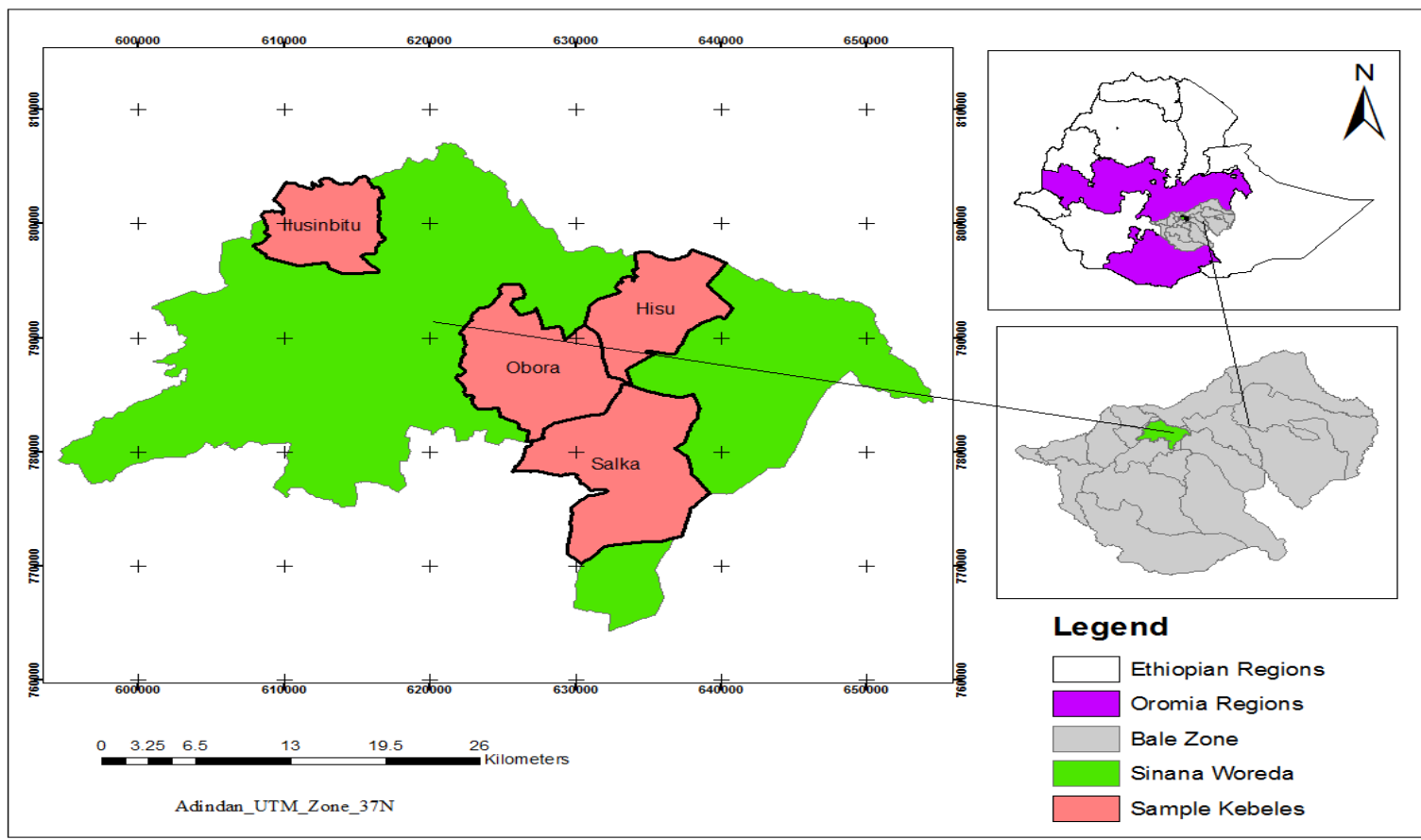

Figure 1.1: Map of the study area

Source: Own GIS Work (2018)

\subsection{Study design}

The study was conducted to investigate impact of glyphosate on agricultural soil quality in the Sinana woreda. To obtain appropriate information the investigator was used laboratory analysis research design with explanatory method which was chosen for the fact that it was provided comprehensive information about the impact of glyphosate applied to agricultural land on soil quality at different rates of dosage.

\subsection{Sampling Techniques}

In this study a multi staged sampling techniques were employed. In the first stage, the study woreda, Sinana was selected purposively considering its recurrent experiences to the decline of soil quality, high productive area, application glyphosate pesticides and decline of crops in the study area. Secondly, four kebeles from 20 kebeles were selected purposively based on the history of use of glyphosate in agricultural land and impacts on soil quality shocks on farmers and in consultation with woreda's expert in the study area. And the farmlands also were selected from this kebeles. Moreover, these four kebeles farm lands were selected due to their history of use of glyphosate than the remaining ones.

\subsection{Sample Sites Design for Application of Glyphosate}

The study sites design was established in four farm lands, all selected farm lands design was based on the homogeneity criteria, slope characteristics and management of cultivated fields under farmer practices. And named as the following; Farm land - Illu Sambitu site; Farm land -Hisu site; Farm land -Obora site; Farm land -Salka site.

\subsection{Application of Glyphosate}

The commercial product Roundup (Monsanto, Sino chem International Corporation) containing $360 \mathrm{~g}$ acid equivalent L- ${ }^{1}$ glyphosate as an isopropyl amine salt was selected for the experiment. The aim of the experiments 
were to test the short-term glyphosate application consequence on Agricultural soil quality at different rate application, neither farm lands soil had a significant known history of fertilizer used. Glyphosate was sprayed at four different rates of doses $\left(0,1,2.5\right.$, and $\left.31 / \mathrm{ha}^{-1}\right)$ were used as experimental materials (treatments). The experiment was laid out in a randomized complete block design (RCBD). It replicated two times per treatment. The experiment was conducted over four farm lands. There were 32 total experimental plots. Plot size was $2 \mathrm{~m}$ by $2 \mathrm{~m}$ and 0.5 meter spaces between plots. During herbicide sprays, plastic sheet was used to separate the plot being sprayed from the adjacent plots to prevent inter-plot interference of spray drift. The company recommended dose was $2.5 \mathrm{~L}^{-\mathrm{ha}^{-1}}$ (at $88 \mathrm{ml}$ in $15 \mathrm{~L}$ sprayer) (Monsanto, 2011). Glyphosate applied management practices weeding control was applied as general recommendation for herbicide during the spraying the sky clear and soil moist (Parionset al., 2003).

\subsection{Soil Sample Collection}

After application of glyphosate visible symptoms develop in 3-7 days but complete desiccation may take 20-30 days (Monsanto, 2011). The risk of glyphosate injury from soil residues with increasing time between spraying for weed control and transplanting into the treated area (Cornish \& Burgin, 2005). After 35 days of glyphosate application the samples were taken from five points of the plot by measuring $2 \mathrm{~m} \times 2 \mathrm{~m}$ quadrant, one at the center and the other four at the corners of the quadrants. These collected samples were mixed to form a composite in order to reduce variability within the quadrants. A total of thirty two soil samples with a replication of two were taken from the selected farm land site; In addition, total of thirty two soil core samples were also collected for soil bulk density and soil moisture content analysis for each of the sampling sites. Eight composite samples were collected for each block at a depth of $20-\mathrm{cm}$ by using auger. Composite sample methods were used for soil collection because of composite sampling units in to single sample effective methods for obtaining an accurate estimate of the population mean, reducing cost and analytical time, the same volume represents a homogeneous sample, each sample contributes an equal amount to the composite, there are no interactions between the samples units with a composite that would significantly the composite value when these conditions are met, values from composite agree well means obtained from single sample units(Jackson 1958). The collected soil samples were pooled and mixed thoroughly in a basket and $500 \mathrm{~g}$ of soil sample was taken for analysis. The soil samples were been air-dried, passed through $2 \mathrm{~mm}$ sieve for physico-chemical analysis.

\subsection{Soil Laboratory Analyses}

The soil physical and chemical analysis was carried out at Soil and water analysis laboratory. Standard laboratory procedures were followed to determine the soil physico-chemical properties (Sahlemedhin \& Taye, 2000).

\subsection{Results and Discussion}

\subsection{Impacts of glyphosate on selected chemical properties}

One of the other objectives of this study is to know the impact of glyphosate on soil quality in comparison between treated farm plots and untreated farm plots by assessing the chemical properties of the sample soils. The chemical property analysis of the different dosage farm lands was explained as indicated in Table 3.1. The soil analysis result of each soil quality indicators under the over dosage fields application were compared with the under dosage, company recommendation application fields as well as the reference control farm lands study area. Table 3.1 shows that the results of mean values $( \pm)$ standard error of mean (SEM) of soil chemical properties for over dosage, under dosage and company recommendation application and control.

The presences of significant difference between the farm land sites were determined by multiple comparisons Test using LSDA at 5\% confidence interval level. 
Table 3.1: the mean value of physicochemical properties of soil analysis of treated and untreated fields

\begin{tabular}{|c|c|c|c|c|c|}
\hline \multirow[t]{2}{*}{ Sites } & \multirow[t]{2}{*}{ Soil properties } & \multicolumn{4}{|l|}{ Treatments } \\
\hline & & Over dosage & Company recommendation & Under dosage & Control \\
\hline \multirow[t]{11}{*}{ Salka site } & $\mathrm{pH}$ & $6.145 \pm 0.645$ & $6.840 \pm 0.010$ & $6.845 \pm 0.005$ & $6.900 \pm 0.050$ \\
\hline & Av.P(ppm) & $37.005+1.405 *$ & $18.355 \pm 0.155^{*}$ & $13.655+0.150 *$ & $7.375+0.1250 *$ \\
\hline & OM (\%) & $2.545 \pm 0.105^{*}$ & $2.500 \pm 0.190^{*}$ & $2.180 \pm 0.300^{*}$ & $2.120 \pm 0.080^{*}$ \\
\hline & TN (\%) & $0.300 \pm 0.010^{*}$ & $0.255 \pm 0.005^{*}$ & $0.22 \pm 0.0160^{*}$ & $0.212+0.002 *$ \\
\hline & Av.K (ppm) & $4.025+0.075^{*}$ & $3.595+0.005 *$ & $2.695+0.105$ & $2.135+0.015$ \\
\hline & $\mathrm{CEC}\left(\mathrm{Cmol}(+) \mathrm{Kg}_{-}{ }^{1}\right)$ & $49.885+0.036$ & $48.39+0.140$ & $47.685+0.565$ & $47.135+0.115$ \\
\hline & $\mathrm{BD}\left(\mathrm{g} / \mathrm{cm}^{3}\right)$ & $0.620+0.010^{*}$ & $0.64+0.000$ & $0.64+0.000^{*}$ & $0.67 \pm 0.100^{*}$ \\
\hline & SMC (\%) & $15.095+0.245 *$ & $15.225+0.335^{*}$ & $14.375+0.255^{*}$ & $16.81+0.290^{*}$ \\
\hline & Clay (\%) & $53.500+0.550$ & $52+1.00$ & $55+0.000$ & $53+2.000$ \\
\hline & Silt (\%) & $24.5 \pm 0.500$ & $25 \pm 0.000$ & $23.5 \pm 0.500$ & $23.5 \pm 0.500$ \\
\hline & Sand $(\%)$ & $22+0.000$ & $23+1.000$ & $21.5+0.500$ & $22.25+0.500$ \\
\hline \multirow[t]{11}{*}{ Illu sambitu site } & $\mathrm{pH}$ & $6.525 \pm 0.275$ & $6.525 \pm 0.250$ & $6.57 \pm 0.170$ & $6.99 \pm 0.005$ \\
\hline & Av.P (ppm) & $12.2+0.300^{*}$ & $9.69+0.1100^{*}$ & $8.35+0.450 *$ & $7.7 \pm 0.2000 *$ \\
\hline & OM $(\%)$ & $2.585+0.315$ & $2.15+0.100$ & $2.205+0.050$ & $2.03+0.080$ \\
\hline & TN (\%) & $0.235+0.015$ & $0.225 \pm 0.015$ & $0.145+0.035$ & $0.185+0.025$ \\
\hline & Av.K (ppm) & $2.765 \pm 0.105^{*}$ & $2.65 \pm 0.000$ & $2.54 \pm 0.110$ & $2.36 \pm 0.030 *$ \\
\hline & $\mathrm{CEC}\left(\mathrm{Cmol}(+) \mathrm{Kg}_{-}{ }^{-1)}\right.$ & $52.605+0.5500^{*}$ & $51.135 \pm 0.515^{*}$ & $49.475 \pm 0.475^{*}$ & $48.625+0.625^{*}$ \\
\hline & $\mathrm{BD}\left(\mathrm{g} / \mathrm{cm}^{3}\right)$ & $0.635+0.005^{*}$ & $0.58+0.010^{*}$ & $0.530+0.010^{*}$ & $0.65+0.0100^{*}$ \\
\hline & SMC(\%) & $13.21+0.100$ & $14.425+0.015^{*}$ & $12.58+0.07 *$ & $14.54+0.310^{*}$ \\
\hline & Clay(\%) & $54+1.000^{*}$ & $53.5+0.500$ & $49.5+0.500$ & $51.5+1.500 *$ \\
\hline & Silt(\%) & $17.5+0.500 *$ & $18+0.000^{*}$ & $19 \pm 1.00$ & $20.5+0.500 *$ \\
\hline & Sand(\%) & $28.5+0.500$ & $28.5+0.500$ & $31.5+1.500$ & $28+1.000$ \\
\hline \multirow[t]{11}{*}{ Hisu site } & $\mathrm{pH}$ & $5.98 \pm 0.130^{*}$ & $6.135 \pm 0.150^{*}$ & $6.26 \pm 0.160 *$ & $6.66 \pm 0.150^{*}$ \\
\hline & $\mathrm{P}(\mathrm{ppm})$ & $6.8+1.35$ & $5.975+0.545$ & $5.305+0.150$ & $5.17+0.050$ \\
\hline & $\mathrm{OM}(\%)$ & $3.805 \pm 0.550 *$ & $2.31 \pm 0.250^{*}$ & $2.12 \pm 0.100^{*}$ & $2.06 \pm 0.500 *$ \\
\hline & $\mathrm{TN}(\%)$ & $0.32+0.100^{*}$ & $0.3+0.100 *$ & $0.27 \pm 0.020^{*}$ & $0.235+0.005^{* *}$ \\
\hline & $\mathrm{K}(\mathrm{ppm})$ & $1.815+0.050$ & $1.64 \pm 0.160$ & $1.585+0.156$ & $1.57 \pm 0.160$ \\
\hline & $\mathrm{CEC}\left(\mathrm{Cmol}(+) \mathrm{Kg}_{-}{ }^{1)}\right.$ & $40.17+2.330$ & $39.07 \pm 2.510$ & $37.46+1.130$ & $37.04 \pm 0.510$ \\
\hline & $\mathrm{BD}\left(\mathrm{g} / \mathrm{cm}^{3}\right)$ & $0.73+0.010^{*}$ & $0.815+0.015^{*}$ & $0.66 \pm 0.010 *$ & $0.895+0.005 *$ \\
\hline & SMC & $10.655+0.595^{*}$ & $10.845+0.495^{*}$ & $9.715+0.805^{*}$ & $14.645+0.005^{*}$ \\
\hline & Clay(\%) & $42.5+0.500$ & $42+0.000$ & $44+0.000$ & $42.5+0.500$ \\
\hline & Silt(\%) & $20.5+0.500$ & $22+0.000$ & $21.5+0.500$ & $21+1.00$ \\
\hline & Sand & $37 \pm 0.000$ & $36+0.000$ & $35+1.000$ & $36.5 \pm 0.500$ \\
\hline \multirow[t]{11}{*}{ Obora site } & $\mathrm{Ph}$ & $5.925+0.125^{*}$ & $6.345+0.095^{*}$ & $6.375+0.055^{*}$ & $6.93+0.055^{*}$ \\
\hline & AvP(ppm) & $5.915+0.135^{*}$ & $5.15+0.180^{*}$ & $4.455+0.015^{*}$ & $4.38+0.380^{*}$ \\
\hline & $\mathrm{OM}(\%)$ & $2.915+0.035 *$ & $2.55 \pm 0.100 *$ & $2.335+0.115^{*}$ & $2.115+0.105^{*}$ \\
\hline & $\mathrm{TN}(\%)$ & $0.26+0.010^{*}$ & $0.255+0.005^{*}$ & $0.25+0.000^{*}$ & $0.22+0.000 *$ \\
\hline & AvK(ppm) & $2.945+0.005 *$ & $2.485+0.035^{*}$ & $2.35+0.020 *$ & $2.135+0.085^{*}$ \\
\hline & $\mathrm{CEC}\left(\mathrm{Cmol}(+) \mathrm{Kg}_{-}{ }^{1)}\right.$ & $47.94+0.560$ & $46.63+0.070$ & $52.365+0.515$ & $52.61+0.740$ \\
\hline & $\mathrm{BD}\left(\mathrm{g} / \mathrm{cm}^{3}\right)$ & $0.61 \pm 0.000^{*}$ & $0.665 \pm 0.005^{*}$ & $0.645 \pm 0.005^{*}$ & $0.685 \pm 0.005^{*}$ \\
\hline & SMC(\%) & $13.13+0.010$ & $13.305+0.025$ & $13.19+0.050$ & $13.67+0.020$ \\
\hline & Clay(\%) & $44.5 \pm 1.500^{*}$ & $43.5+0.500^{*}$ & $50 \pm 1.000 *$ & $48.5 \pm 0.500^{*}$ \\
\hline & Silt(\%) & $28.5 \pm 1.500^{*}$ & $30 \pm 2.000 *$ & $22.5 \pm 0.500 *$ & $22.5 \pm 0.500 *$ \\
\hline & Sand $(\%)$ & $27+0.000$ & $26.5+1.500$ & $27+0.000$ & $29+0.000$ \\
\hline
\end{tabular}

Mean values with the * significantly different at $\alpha=0.05$

\subsubsection{Soil pH}

Soil $\mathrm{pH}$ is one of the soil chemical properties that indicate soil quality at the study sites. From table 3.1 , the mean values of $\mathrm{pH}$ for the over dosage are 6.145, 6.525, 5.98 and 5.92 for Salka, Illu sambitu, Hisu and Obora Sites respectively. And the mean $\mathrm{pH}$ values for company recommendation dosage glyphosate were $6.145,6.525,5.98$ and 5.92 for Salka, Illu sambitu, Hisu and Oborasites respectively. The mean $\mathrm{pH}$ values for the under dosage glyphosate applied were 6.84, 6.57, 6.26 and 6.37 respectively for the Salka, Illu sambitu, Hisu and Obora, however the mean value $\mathrm{pH}$ for control sites were $6.69,6.99,6.66$ and 6.39 respectively for the Salka, Illu sambitu, Hisu and Obora sites. The $\mathrm{pH}$ value decreased from control to over dosages which indicate that application of glyphosate to farmland will increases the soil acidity. Similar study with a general trend of increase glyphosate adsorption with decrease $\mathrm{pH}$ was observed (Eduardo et al , 2017). The ANOVA result shows that there were a significant difference in mean $\mathrm{pH}$ among the Hisu and Obora farm land sites, but no significant variation among Salka and Illu sambitu sites. The LSD result showed that the mean $\mathrm{pH}$ of over dosage and company recommendation applied to farmlands were significantly higher $(\mathrm{p}<0.05)$ than under dosage and control for Hisu farmland but for Obora site, Significance variation was observed.

3.1.2. Organic carbon

A well-structured soil has properties that enhance soil quality, by providing an environment to encourage the 
growth of healthy crops by maintaining adequate moisture, support desirable organism growth which can take residues and turn them into more organic matter $(\mathrm{OM})$. As described in table 3.1. The laboratory result was determined for the four treatments through further analysis so as to identify the presence of significant differences between the Over dosage, Company recommendation, under dosage and Control. The mean OM content among the four farm land sites; over dosage treatment contains higher OM than company recommendation, under dosage and Control, because of Glyphosate contain organic carbon. This finding agreed with the study of (Sabiomo et al., 2011) organic carbon is increasing after application of six weeks we compared to controls soil. Microorganism used for energy source to an increased availability of easily degradable carbon compounds from applied the glyphosate (Imparato et al., 2016)

\subsubsection{Total nitrogen (TotN)}

As result from table 3.1; the mean values of total nitrogen (TN) were found to be greater in over dosage treatments than the Company recommendation, under dosage and Control for the Hisu, Salka, Obora and Illu sambitu sites. The short term application of glyphosate increased the total of nitrogen for short period of time; nitrogen is present in glyphosate herbicide important for plant growth. Glyphosate use results in minor effects on soil properties, including microbial communities. They speculated that the enhanced nitrogen, organic carbon and plant residues in surface soils under conservation practices buffer potential effects of glyphosate on biological and chemical properties of soil (Antonio \& Stephen, 2010). The statistical test of LSD proves that the mean of TN content for treatments of over dosage, company recommendation, under dosage and Control has been observed at all sites except Illu Sambitu site. On the other hand, ANOVA results shown there is a significant difference was observed at $\mathrm{P}<0.05$ between Hisu, Salka and Obora farm land sites.

\subsubsection{Available phosphorus (AvP)}

The mean values of available phosphorus higher in over dosage application of glyphosate among all four farm lands; because glyphosate herbicides contain phosphorous element. Glyphosate may become easily mobile by water in soils high in phosphate. Phosphate in fertilizers reduces the adsorption of glyphosate to soil particles, increasing the amount of free glyphosate molecules in the soil, which can then be absorbed by the plant roots, metabolized by microorganisms (Munira et al., 2016).Due to the presence of phosphorous fertilizer in glyphosate the amount of available phosphorous increased. Similar study done by (Mijangos et al., 2009) reported glyphosate increases soil microbial activity when the herbicide is added; because microbes break it down and use it as a source of carbon, nitrogen or phosphorus. However, this is thought to be due to a short-term effect only. ANOVA one way was used to identify whether the significant differences were exist between the soils of all sites selected. The ANOVA of mean result of AvP among the farmland used was found at $\mathrm{P}<0.05$ significant variation for all farmland sites except Hisu sites. The LSD result showed that the mean AvP values differ significantly under the treatments in Illu, Salka and Obora sites, significance variation was observed among the dosage. When compared the control farmland with applied farm land, the available of phosphorous was high on applied farm land. This might be due to the presence of phosphorous fertilizer in glyphosate.

3.1.5. Available potassium (AvK)

When we consider the mean values of available potassium (AvK), no significant different were observed for the Hisu farm land sites in all treatments. Only over dosage treatment had significant difference in illu site, while over dosage and company recommendation were significantin salka site andall treatments were significance in Obora sitestable 3.1. ANOVA result for mean AvK was found at $\mathrm{P}<0.05$ under the Salka, and Oborasites. The LSD results showed at Salk site.

\subsubsection{Cation exchange capacity}

Cation exchange capacity is an important parameter of soil because it gives an indication of the type of minerals present in the soil, its capacity to retain nutrients against leaching and assessing their fertility and environmental behavior. The CEC values of the soils in the study area were only significantly difference at Illu sambitu sites for over dosage, under dosage and company recommendation Table 3.1. ANOVA result for mean CEC was found at $\mathrm{P}<0.05$ under the all sites except Salka.

\subsection{Impacts of short term application glyphosate on soil physical properties 3.2.1. Bulk density}

The mean values of bulk density under all sites were significantly different among each other. But, in Salka site the company recommendation application of glyphosate did not show significant difference Table 3.1. ANOVA was used to test the significance of the differences between the means of BD all sites were significance at $\mathrm{P}<0.05$ because of short term application of glyphosate on agricultural farmland. When compared mean values, control farm land was high bulk density. With increasing organic carbon, bulk density decreased. This study agreed with (Mohamed, 2013) report. In general, soils with good structure have higher pore space and lower bulk density.

\subsubsection{Texture}

The particle size distribution in all sample fields presented soil texture in (Table 3.1) the study area soil refers to the clay, silt and sand composition. In the study area the soil texture was more of clay texture. The clay soil has 
significant difference at Obora site in all treatments but in Illu Sambitu only over dosage treatment. Clay content has retention capacity of nutrient and water. Clay soils resist impact of glyphosate because the particles are more tightly joined to each other. The finding was agreement with the study of (Strange - hansen et al., 2004). Clay soil resists glyphosate degradation. This result was similar with the study of (Simonsen et al., 2008) degradation soil quality application of glyphosate low clay. Soil texture is a basic property of soil that affects soil physical properties and management. Under normal conditions, it is considered as a permanent property of a soil. Soil texture affects soil water and nutrient holding capacities and air movements, pore sizes and plant root growth. Because of these important roles, soil texture is considered as a master soil variable.

As laboratory results showed the mean of sand soil was not significance for short term application of glyphosate in all study sites table 3.1. ANOVA was used to test the significance of the differences between the means of sand soil all sites were not significant at $\mathrm{P}>0.05$ except Obora site. The mean of silt soil particles only significant at Obora sites on all treatments but in Illu sambitu sites, the over dosage, company recommendation and control treatments were significant table 4.6. The ANOVA analysis showed the significance at $\mathrm{P}<0.05$ in all sites except in Obora site.

\subsubsection{Soil moisture content (SMC)}

It is influenced by many factors like: soil texture, depth, structure, organic-matter and temperature (Assefa, 2009). The mean values of SMC showed significance difference in all farmland sites except Obora site shown as table 3.1. The ANOVA analysis showed the significant difference at $\mathrm{P}<0.05$ in all sites. The adsorption of glyphosate is influenced by physical soil conditions such as structure, organic matter content and water infiltration rate (Candela et al. 2007).

\subsection{CONCLUSIONS}

Improper application of Pesticide on agricultural land is one of the major environmental concerns that adversely affect livelihoods. The long term application of glyphosate leads to decline of soil fertility; this further decreases the crop yield. The laboratory analysis revealed, short term application of glyphosate has a slight impact on some soil physicochemical properties. According to survey results the continuous intensive application of glyphosate area without appropriate soil management has affected most of the important soil characteristics. Therefore, reducing intensive glyphosate in control weed, and integrated use of glyphosate practices could replenish the soil characteristics for sustainable agricultural production and productivity in the study area.

\subsection{RECOMMENDATIONS}

The following recommendations are important and need to be considered to enjoy more effects by addressing the constraints of the farmers.

$>$ There is a need to strengthen the scientific basis of modern agriculture, because herbicides may be useful if their persistence, bioaccumulation, and toxicity in agro-ecosystem are strictly controlled.

$>$ Agricultural Development Project (ADP), stake holders and governments conducted organize training for rural farmers on application of herbicides and farmers should form associations so as to pull resources together, buy herbicides directly from the distributors.

$>$ Short term application of glyphosate is not affected some soil chemical properties available of potassium, organic matter, total nitrogen and available phosphorus quality so the farmers should use in proper manner to remove the challenges of weeds from the agricultural farm lands.

$>$ The researcher faced problems while trying to take soil samples for short term application of glyphosate from farm fields. Besides, this study doesn't incorporate long term impact of glyphosate on agricultural soil quality. Thus, further studies need to be conducted to correct the cited problems of this study as well as covering a larger area.

$>$ The investigator was not conducted on health impact the sprayers, so further studies need to be conducted on problems of human health.

\section{ACKNOWLEDGEMENTS}

We are much obliged in thanking Sinana Agricultural Office and Developmental agents for the technical and professional support rendered during our study.

\section{REFERENCES.}

Al-Rajab, A. Amellal, S., \&Schiavon, M.(2008). Sorption and leaching of (14) C-glyphosate in agricultural soils. Agronomy for Sustainable Development, 28: 419-428.

Antonio, L.,\& Stephen, O.(2010). Effects of glyphosate-resistant crop cultivation on soil and water quality

Asefa, M. (2009). Assessment of adaptation behavior of soils and water conservation practices in the Koga watershed, highlands of Ethiopia: at Cornell University.

Barnes, R. (2000). Why the American Soybean Association supports transgenic soybeans.Pest. Manage. Sci. 56: 
580-583.

Battaglin, W. Meyer, M. Kuivila, K., \&Dietze,J. (2014). Glyphosate and its degradation product AMPA occur frequently and widely in US soils, surface water, groundwater, and precipitation. JAWRA Journal of the American Water Resources Association, 50: 275-290.

Benbrook, C.(2016) Troubled times amid commercial success for Roundup Ready soybeans. http://www. mindfully.org/GE/GE2/RRS-Troubled-Benbrook.htm. Accessed

Black, C.(1965). Methods of soil analysis. Part I, American society of agronomy. Madison, Wisconsin, USA. 1572.

Booker.(1991). A handbook for soil survey and agricultural land evaluation in the tropics and sub-tropics.tropical soil manual, JR, London.

Borggaard, O., \&Gimsing,A. (2008). Fate of glyphosate in soil and the possibility of leaching to ground and surface waters: A review, Pest Management Science, 64:441-456.

Bouyoucos, G. (1962). Hydrometer method improved for making particle size analysis of soil. Agronomy Journal, 54: 464-465.

Brady, N., \& Weil, R. (2002). The nature and properties of soils.(13 $3^{\text {th }}$ ed.). Macmillan publishing company, New York, USA. 960.

Brookes, G., \&Barfoot, P. (2015). Environmental impacts of genetically modified (GM) crop use 1996. Impacts on pesticide use and carbon emissions. GM Crops Food, 6:103-33.

Bryceson, D. (2002). The scramble in Africa: Reorienting rural livelihoods. World Development, 30(5), 725-739.

Candela, L.Alvarez-Benedi, J, De Melo, M., \&Rao, P. (2007). Laboratory studies on glyphosate transport in soils of the Maresme area near Barcelona, Spain: Transport model parameter estimation. Geoderma, 140(1), 8-16.

Candela, L. Caballero, J., \& Ronen,D. (2010).Glyphosate transport through weathered granite soils under irrigated and non-irrigated conditions.Barcelona, Spain. Science of the Total Environment, 408: 2509-2516.

Carlisle, S., \& Trevor, J. (1988).Glyphosate in the environment. Water, Air and Soil Pollution, 39: 409-420.

Carter, M. (2002). Soil quality for sustainable land management: Organic matter and aggregation interactions that maintain soil functions. Agronomy Journal, 94:38

Chapman, H. (1965). Cation exchange capacity. In: Black, C.A., Ensminger, L.E. and Chen ZS, Hsieh CF, Jiang FY, Hsieh TH, Sun IF (1997). Relations of soil properties to topography and vegetation in a subtropical rain forest in southern Taiwan. Plant Ecology, 132(2):229-241.

Clancy, K. (2010). Managing potassium nutrition/www.fusionfert.com/accesed date, 17/07/2010; 10:47.

Cornish, S., \& Burgin, S. (2005).Residual effects of glyphosate herbicide in ecological restoration. Ecology No. 4, 13, "Vol.", 695-702.

CSA. (2007). Population and Housing Census of Ethiopia: Results for Oromia Region, "Vol.", 1 Addis Abeba.

Cuhra,M.,Traavik,T.,Dando,M.,Primicerio,R.,Holderbaum,D.F., $\quad$ \&Bøhn,T. $\quad$ (2015).Glyphosateresiduesinroundup-readysoybeanimpairDaphniamagnalife-cycle. J.Agric.Chem.Environ. 4,24.doi:10.4236/jacen.2015.41003

Damin,V.Trivelin, P. Franco, H., \& Barbosa, T. (2010a).Nitrogen (15N) loss insoil-plant system after herbicides application in Penissetumglaucum. Plant and Soil,328; 245-252.

De Jonge, H. De Jonge, L., \& Jacobsen O. (2000). Glyphosate transport in undisturbed topsoil

Columns.Pest Management Science, 56: 909-915.

Dion, H. Harsh, J., \& Hill, H. (2001).Competitive sorption between glyphosate and inorganic phosphate on clay minerals and low organic matter soils.J RadioanalNuclChem, 249:385-390.

Derpsch, R. (1998). Historical review of no-tillage cultivation of crops. The $1^{\text {st }}$ JIRCAS seminar on Soybean research.no-tillage cultivation and future research needs no. 13: 1-18.

Duke, S., Lydon, J., Koskinen, W., Moorman, T., Chaney, R., Hammerschmidt, R., \&(2012). Glyphosate effects on plant mineral nutrition, crop rhizospheremicrobiota, and plant disease in glyphosate-resistant crops. J. Agric. Food Chem. 60, 10375-10397.

Eduardo, D. Virginia, A., \&José Luis ,C. (2017) Effects of $\mathrm{pH}$ and phosphate on glyphosate adsorption to Argentina soils.

FAO. (2005). The importance of soil organic matter: Key to drought resistant soil and sustained food production. FAO Soils Bulletin, No. 80.Food and agricultural organization of United Nation, Rome, Italy 65: 11-47.

Fotyma, M. (2007).Content of potassium in different forms in soils of Southeast Poland,Polishn Journal of Soil Science, vol.xi/1, PL ISSN 0079-2985.

Franz, J. Mao, M., \&Sikorski, J. (1997).Glyphosate.A unique global herbicide.ACS Monograph 189. Washington D.C. American Chemical Society.

Gardiner, D., \& Miller, R. (2004). Soils in Our Environment.(10 ${ }^{\text {th }}$ ed.).Pearson Education, Inc., Upper Saddle River, New Jersey. 07458.

Giesy, J. Dobson, S., \& Solomon, K. (2000). Eco toxicological risk assessment for Roundup (R) herbicide.Inreviews of environmental contamination and toxicology, 167 "Vol" (G. W. Ware, 
ed.).167“Vol”:35-120.

Gimsing, A. Borggaard, O., \& Bang, M. (2004). Influence of soil composition on absorption of glyphosate and phosphate by contrasting Danish surface soils. Eur. J. Soil Sci, 55: 188-191.

Gregorich, L., \& Acton, D. (1995). The health of our soils toward sustainable agriculture in Canada. Centre for land and biological resources research, Ottawa, Canada, 5-10.

Ibitayo, O.(2006). Egyptian farmers' attitudes and behaviors regarding agricultural pesticides: Implications for pesticide risk communication. Risk Analysis, 26: 989-995.

Imparato, V.Santos, S, Johansen, A.Geisen, S., \& Winding, A. (2016). Stimulation of bacteriaand protists in rhizosphereof glyphosate-treated barley, Applied Soil Ecology, 98:47-55.

Jackson, M. (1958).Soil chemical analysis. Practice-Hall,Englewood Cliffs, new Jersey,USA.

Kettler, T. Doran, W.,\& Gilbert, T. (2001). Simplified method for soil particle size determination to accompany soil quality analyses.Soil Science Society of American Journa, 65:849-852.

Klute, A. (1965). Water holding capacityC.A.Black (eds.). Methods of Soil analysis.American society of Agronomy No. 9, Wisconsin, USA, 273-278.

Kortekamp, A. (2011). Herbicides and environment.PublishInTech.JanezaTrdineRijeka, Croatia.

Lancaster, S. Hollister, E.Senseman, S., \& Gentry, T. (2009).Effects of repeated glyphosate applications on soil microbial community composition and the mineralization of glyphosate.Pest Management Science, 66: 5964.

Liu, E. Yan, X. Mei, W. He, S. Bing, L. Ding, Q. Liu, S., \&Fan,T. (2010). Long-term effect of chemical fertilizer, straw and manure on soil chemical and biological properties in northwest China.Geoderma, 158: 173-180.

Livingston, M. Fernandez-Cornejo, J. Unger, J. Osteen, C. Schimmelpfennig, D., \& Park, T. (2015). The economics of glyphosate resistance management in corn and soybean production.United States Department of Agriculture, Economic Research Service.

Majewski, M. Coupe, R. Foreman, W., \&Capel, D. (2014). Pesticides in Mississippi air and rain: A comparison between 1995 and 2007. Environmental Toxicology and Chemistry, 33: 1283-1293.

Mensah,P.Muller,W., $\quad$ \&Palmer,C.(2012).Usinggrowth

measures inthefreshwatershrimpCaridinaniloticaasbiomarkersofRoundup(R) pollutionofSouthAfricanfreshwatersystems. Phys.Chem.Earth50-52, $262-$ 268.doi:10.1016/j.pce.2012.08.003

Mesfin, A. (1998).Nature and Management of Ethiopiansoils.Alemaya University of Agriculture, Ethiopia.

Michaelidou,C.Piera, P., \&Nicolaou, S. (2000). Evaluation of combination toxic effects and geno toxicity of pesticides for environmental protect and sustainability. Proceeding of the $1^{\text {st }}$ European conference on pesticides and related organic micro pollutants in the environment (T. Albanis ed.),Ioannina, Greece. 49-52.

Mijangos, I. Becerril, J. Albizu, I Epelde, L., \&Garbisu, C. (2009). Effects of glyphosate on rhizosphere soil microbial communities under two different plant compositions by cultivation-dependent and independent methodologies, Soil Biology \& Biochemistry, 41: 505-513.

Milosevia, N., \&Govedarica, M. (2002).Effect of herbicides on microbiological properties of soil.Proceedings for Natural Sciences.MaticaSrpska Novi Sad,102: 5-21.

Mohamed,Y. (2013). Selected Soil Quality Indicators under Different Land Use, Management and Soil Types at Pawe, Northwestern Ethiopia.

Monsanto.(2011). Roundup Herbicide ApprovedWater soluble herbicide for non-selective control of many annual and perennial weeds in certain situations.

Munira, S.Farenhorst, A. Flaten D., \&Grant, C. (2016). Phosphate Fertilizer Impacts on Glyphosate Sorption by Soil. Chemosphere, 153: 471-477.

Nortcliff, S. (2002).Standardization of soil quality attributes. Agriculture, Ecosystem and Environment, 88:161168.

Olsen, S. Cole, C. Watnahe, F.,\& Dean, L. (1954). Estimation of available phosphorous in soils by extraction with Sodium bicarbonate,USDA Circular. 939:1-19.

Parionsss, W. Fredericksen,T., \&Licons, J. (2003). Natural regeneration and liberation of timber species in logging gas in two Bolivian tropical forests. Forest Ecology and management, 181, "vol"no. 3, 313 - 322.

Piccolo, A.Celano, G.,\& Conte, P. (1996).Adsorption of glyphosate by humic substances. J. Agric. Food Chem,44: 2442-2446.

Piesova, E. (2005). The effect of glyphosate on the frequency of micronuclei in bovine lymphocytes in vitro.ActaVeterinaria (Biograd), 55(2-3), 101-109.

Powles, S. (2008).Evolved glyphosate-resistant weeds around the world: lessons to be learnt. Pest ManagSci 64:360-5.

Rampazzo.N.Todorovic ,G. Mentler, A., \& Blum, W,.(2013). Adsorption of glyphosate andaminomethylphosphonic acid in soils. International Agrophysics ,27: 203-209.

Ruiz-Toledo, J. Castro, R. Rivero-Perez,N. Bello-Mendoza, R., \& Sanchez, D. (2014). Occurrence of Glyphosate 
in Water Bodies Derived from Intensive Agriculture in a Tropical Region of Southern Mexico. Bulletin of Environmental Contamination and Toxicology, 93: 289-293.

Sahlemedhin, S., \&Taye,B. (2000). Procedures for soil and plant analysis paper74, national soil research center, Ethiopian Agricultural Research Organization (EARO), Addis Ababa, Ethiopia.

Salameh, P.(2004). Pesticides in Lebanon: a knowledge, attitude, and practice study. Environmental Research,94: $1-6$.

Samsel, A., \&Seneff, S. (2015). Glyphosate pathways to modern diseases IV: cancer and related pathologies. Journal of Biological Physics and Chemistry, 15: 121-159.

Schutte, G. (2003). Herbicide resistance: Promises and prospects of Biodiversity for European Agriculture. Agriculture and human values, 20 (3), 217-230.

Shirani, H. Hajabbasi, M. Afyuni,M., \&Hemmat,A. (2002). Effects of farm yard manure and tillage systems on soil physical properties and corn yield in central Iran. Soil and Tillage Research, 68: 101-108.

Sebiomo, A. Ogundero, V., \&. Bankole,S.(2011).Effect of four herbicides on microbial population, soil organic matter and dehydrogenase activity.African Journal of Biotechnology Vol. 10(5), pp. 770-778

Simonsen, L. Fomsgaard,I.Svensmark, B.,\&Spliid,N. (2008). Fate and availability of glyphosate and AMPA in agricultural soil. Journal of Environmental Science and Health Part B Pesticides Food Contaminants and Agricultural Wastes, 43: 365-375.

SinanaWeredas Agricultural Office.(2017). Bale Robe Oromial Regional State South Eastern Ethiopia.

Strange-Hansen, R. Holm, P. Jacobsen, O.,\& Jacobsen, C.(2004) Sorption, mineralization and mobility of N(phosphonomethyl)glycine (glyphosate) in five different types of gravel. Pest Management Science,60: 570578.

Sullivan,P.(2004). Sustainable soil management.Soil systems Guide, NCAT, California.Cropping systems effects on soil quality in semi-arid tropics.Journal of Sustainable Agriculture, 16(3).

Teamti,T., \&Tesfay,A. (2016). Farmers' perception on glyphosate application in conservation agriculture system of Northern Ethiopia Journal International of African and Asian Studies, 17 "Vol”.:32-34.

Tigist,P(2010)Adoption of conservation tillage technologies in Metema woreda, North Gondar Zone, Ethiopia.

Todorovic, G. Rampazzo, N.Mentler, A. Blum, W.Eder, A., \& Strauss, P. (2014).Influence of soil tillage and erosion on the dispersion of glyphosate and aminomethylphosphonic acid in agricultural soils. International Agrophysics, 28: 93-100.

Topp,C.Dow,B. Edwards,M. Gregorich,E. Curnoe, W., \&Cook, E.(2000) Oxygen measurements in the root zone facilitated by TRD. Can J Soil Sci. 80:33-41.

Topp, G. Reynolds, F. Cook, L.Kirby, M., \&Carter,M.(1997). In: Gregorich, E.G. and M.R. Carter (eds.). Soil Quality, Physical attributes of soil quality. 21-52

USDA.(2008). Soil quality indicators.USDA, Natural resources conservation Service, Nyle C. Brady, Macmillan.

Van Reeuwijk, L. (1993). Procedure for soil analysis, (4 ${ }^{\text {th }}$ ed.). International soil reference center Wageningen. (ISRIC) technical paper no. 9. The Netherlands, Wageningen. 371.

Velasqueza,E. Lavelleb, P., \&Andradec, M. (2007). General indicator of soil quality, a multifunctional indicator of soil quality. Soil Biology and Biochemistry, 39: 3066-3080.

Walkley, A.,\& Black, C. (1934).An Examination methods for determining soil organic matter and a proposed modification of the chromic acid titration method, Soil science, 37: 28-38.

Webster,T.Laing,L.Florance,H.,\&Santos,E. (2014). Effects of Glyphosate and its Formulation,Roundup, on Reproduction in Zebrafish. Environmental Science \& Technology, 48: 1271-1279.

White, R. (2006). Principles and practice of soil Science: The soil is the natural resource, (4 ${ }^{\text {th }}$ ed.).Blackwell Publishing, Malden, USA.133-154.

WHO.(1996). Data Sheets on pesticides. Glyphosate, 91:1-15.

Wojtaszek, B. Staznik, B. Chartrand, D. Stephenson, G., \& Thompson, D. (2004).Effects of Vision herbicide on mortality, avoidance response, and growth of amphibian larvae in two forest wetlands.Environmental Toxicology and Chemistry, 23: 832-842.

Woodburn, A. (2002). Glyphosate: Production, Pricing and use Worldwide. Pest. Manage. Sci. 56: 309-31.

Yadav, I. Devi, N. Syed, J. Cheng, Z. Li, J.,\& Zhang, G.(2015). Current status of persistent organic pesticides residues in air, water, and soil, and their possible effect on neighboring countries: A comprehensive review of India. Science of The Total Environment, 511: 123-137.

Yamane, T. (1967).Statistics, an introductory Analysis (2 $2^{\text {nd }}$ ed.). New York.

Zaller, J. Heigl, F. Ruess, L.,\&Grabmaier, A. (2017).Glyphosate Herbicide Affects Belowground Interactions between Earthworms and Symbiotic Mycorrhizal Fungi in a Model Ecosystem.Scientific Reports 4: 5634.

Zhang ,C.Hu,R.Shi G, Jin ,Y. Robson ,G., \& Huang, X.(2015). Overuse or underuse? An observation of pesticide use in China.Science of.The Total Environment; 538: 1-6.

Zobiole,L.Kremer,R.Oliveira,R.,\&Constantin,J.(2011).Glyphosateaffectschlorophyll,nodulationanutrientaccumul ationof"secondgeneration"glyphosateresistantsoybean(Glycinemax L.). Pestic.Biochem.Physiol. 99;53-60. 